Pre-published version

\title{
Cultural studies in education: Filming fluid subjectivities in Indonesian universities
}

\author{
Chiara Logli, University of Hawaii at Manoa
}

\begin{abstract}
This article focuses on the Indonesian film $\operatorname{Cin}(T) a$, which features the interfaith and multiethnic love between two college students. I apply intergroup contact theory, critical pedagogy and grounded cosmopolitanism to the reading of the movie in order to demonstrate two key points. First, higher education is a contact zone, where grounded (i.e. ethnic, religious, and national) and cosmopolitan (i.e. humanist and global) allegiances converge. Second, cultural studies are significant to the field of education, especially when they expand beyond the Anglo-American axis. They complicate 'given' notions of culture and demonstrate how cultural artefacts, like films, are pedagogical instruments. My methodology relies on film analysis, campus observations and interviews with the film-maker as well as with 65 college students, faculty and administrators.
\end{abstract}

\section{Keywords}

Cosmopolitanism, ethnicity, religion, nation, higher education, Indonesia

\section{Introduction}

This paper investigates higher education as a contact zone, where grounded and cosmopolitan allegiances converge. With 'grounded' I intend ethnic, religious and national belongings, whereas with 'cosmopolitan' I refer to both humanist and global influences. In relation to university classrooms, the term 'contact zone' comes from Pratt who describes it as 'social spaces where cultures meet, clash, and grapple with each other, often in contexts of highly asymmetrical relations of power, such as colonialism, slavery, or their aftermaths as they are lived out in many parts of the world today' $(1991,1)$.

The objective of this article is to demonstrate the significance of cultural studies for the field of education, as they complicate 'given' notions of ethnicity, religion and nationhood that are still predominant in educational academic journals (During 2007). Cultural studies of education and the critical use of artefacts as pedagogical tools are relevant, but remain rare (Hytten 1999). In addition, I intend to expand the discourse on diversity in education beyond the dominant Anglo-American axis, by focusing on Indonesia and relying on scholars from Asia. Much of the literature on multicultural education and related fields that addresses issues of diversity stems from debates in the West (Bokhorst-Heng 2007). I would like to broaden that purview by bringing experiences and contexts from Asia. I attempt to further decentre the centre, by drawing attention to the contributions of a majority-Muslim, south-east Asian, 'developing' country like Indonesia, which has received little academic notice compared to Japan, China and India.

This paper is interested in expanding the discourse on intercultural contact within higher education through the analysis of the Indonesian film Cin(T)a (2009). All facets of the film are 
illustrative of how cultures are lived out in people's daily lives and fluid subjectivities. The plot features a tender interfaith romance between two college students from different islands, ethnicities, religions and social classes in Indonesia. The film-maker's personal experience is also revealing for the purpose of this paper, since she is a recent graduate from the multicultural university that is featured in the movie. In addition, the condition of the film enterprise around $\operatorname{Cin}(T) a$ exposes the social fabric on which universities rest. Therefore, both text and context of $\operatorname{Cin}(T) a$ offer a pedagogical terrain where the intricacy of intercultural encounters in education can be investigated. While the analysis of $\operatorname{Cin}(T) a$ is the primary method of my paper, I also draw from my interviews with director Sammaria Simanjuntak as well as with 65 students, professors and administrators at Gadjah Mada University in 2012.

Pratt's definition of contact zone leads the organisation of my conceptual framework (1991). First, I discuss intergroup contact theory which provides evidence in support of the fruitful interactions within a diverse student body. Second, I introduce notions of the public sphere that I tie to critical pedagogy and ethno-national theories, to shed light on students' ethnic, religious and national affiliations. Third, I employ grounded cosmopolitanism to illuminate the relations between contextual and universalist belongings. This interdisciplinary approach informs how sociopolitical constructs affect intercultural contact at the university, without neglecting the active role young people play in this dynamic process of local and global influences. After my theoretical discussion, I present a brief overview of Indonesia, with attention to ethnicity, religion and nationhood. Next, I examine the film $\operatorname{Cin}(T) a$, by integrating my empirical findings with the analysis of the state of the film industry, film-makers' aspirations and deconstruction of the screenplay. Finally, I conclude with some pedagogical implications of integrating films and international sources in the classroom.

\section{University as contact zone \\ Intergroup contact theory}

Since Allport's seminal work on intergroup contact theory for reducing prejudice, scholars have confirmed that spending time together is one of the conditions to overcome ignorance, hostility and segregation (1954). Their studies have found consistent evidence in support of the positive implications of a diverse student body (Halualani et al. 2004; Sorensen et al. 2009; Wright et al. 1997). For instance, universities with greater demographic plurality have more likelihood that students engage in intercultural encounters, hold variable opinions, discuss a multiplicity of topics, and are exposed to in-group and out-group positive exemplars. These intercultural experiences carry further consequences, including the enhancement of students' motivation to promote racial understanding, civic action and social change.

Yet, the type and effectiveness of contact can depend on a variety of elements. According to Antonio, the existence and depth of intercultural friendships on campus rely 'on previous socialisation as well as current social context, and can vary as a social construct linked to culture, social position, or intergroup relations' (2004, 572). Allport (1954) and his followers Robinson and Preston (1976) and Chavous (2005) argue that interracial contact is most prone to reduce prejudice when participants are: (1) of equal status, (2) in a voluntary contact situation, (3) pursuing common goals, (4) in meaningful associations with one another and (5) encouraged by

Logli, C. Cultural studies in education: Filming fluid subjectivities in Indonesian universities. Pedagogy, Culture and Society, online first. http://www.tandfonline.com/eprint/VQvSIx9jn5tFFtQCbCbk/full 
the authorities. In addition, students' contact can benefit from both formal interventions and informal interactions, including rooming, studying together, participating in student organisations, attending campus events and taking time to learn more about others (Engberg 2004; Nagda and Gurin 2007). Thus, students' intercultural encounters do not take place in a void, but in an influential landscape of multiple forces.

\section{Critical pedagogy, public sphere and ethno-nationalist theories}

According to critical pedagogy, universities are public spheres, where both hegemonic and subaltern counter-publics interplay (Giroux 1988). The notion of public sphere originated with Jurgen Habermas in reference to a space that mediates between the state and the private realm (Crossley and Roberts 2004). Fraser argues that there is no one public sphere but rather a plurality of competing publics (2007). While some public spheres serve the hegemony of the dominant group, others host competing 'subaltern counter-publics', namely 'parallel discursive arenas where members of subordinated social groups invent and circulate counter-discourses to formulate oppositional interpretations of their identities, interests and needs' (Fraser 2007, 497). As public spheres, universities may contain a discourse that combines 'the language of critique with the language of possibility' (Giroux 1988, 195).

As referents of critique, universities are denounced for being the terrain out of which the dominant culture manufactures, legitimates and reproduces its hegemonic structures. According to Foucault, a ubiquitous discourse serves to 'normalise' people, by defining and imposing socially acceptable behaviours (1995). Individuals internalise external norms of surveillance and subordinate themselves to regimes of knowledge, which is part of the power relations that create 'the university' and benefit from it. In Bourdieu's notion of learning, students absorb the dominant culture not only via the overt discourse of schools, but also through the persuasive messages embodied in the 'insignificant' practices of daily campus life (1979).

As referents of possibility, universities host forces that interrogate and interrupt constructed meanings and procedures. To promote this resistance, various pedagogical methods are employed, including critical literacy, democratic engagement and authentic pluralism (Hytten 1999). The ultimate goal is to provide students with the knowledge and skills they need to navigate and transform the larger status quo (Giroux 1988). Although studies of education attend to issues of difference, they can neglect to problematise notions of religion, ethnicity, and nation, and their mutual relationships. According to classical theories, the nation is either a continuation of given cultural foundations (Geertz 1973; Smith 2003) or a post-Enlightenment fabrication (Anderson 2006; Hobsbawm and Ranger 1992). Ethnicity and religion are among the pillars of the construction of the nation; yet, religion is often 'ethnicised' so it can be understood through the analysis of ethnicity (Smith 2003). More recent scholarship has moved beyond the primordial-modernist dichotomy, by recognising that a nation may be novel in terms of a system of nation-states, but is ancient in terms of group self-consciousness (Duara 1996; Jiang 2006; Shin 2006). Shin, for instance, argues that ethnic identity is 'embedded' in a particular society and history, 'contingent' (not inevitable), and 'contested' (emerging from contention among different kinds of nationalism or ethnic groups seeking state power) (2006, 8-11). 
In the context of Indonesia, Heryanto echoes the deconstruction of the concept of culture as unchanging, essential and existing from the beginning (1998, 2004, 2008). Heryanto defines ethnicity as a 'modern fiction' (Heryanto 2008, 78) and 'political invention' (2004, 33), which is established to create social cohesion and to legitimise authority. He is concerned about the myths of authenticity that separate 'us' from 'them', and one privileged group from all others. In my investigations within higher education, these sociopolitical divides constrain the effectiveness of intergroup contact. Yet, the potential for agency is not foreclosed because students interact with ethnic, religious and national belongings in a multitude of ways, while also potentially extending their thinking in relation to the larger milieus of universalist values and global trends.

\section{Grounded cosmopolitanism and identity}

Nilan and Feixa write, 'the process of hybridization looks towards an ambivalent and complex third space of cultural practice, in which new authority structures pull young people towards different narratives of identity' $(2006,108)$. Hybridisation is a process of cultural interaction between the local and the global, the hegemonic and the subaltern, the centre and the periphery. Global influences transform in local traditions, locality is assimilated with globality and a hybrid space of new meanings emerges. Hybridisation offers especially young people a place to construct an alternative identity.

In Indonesia, the college students' world is saturated with cosmopolitan forces, including electronic music (Richter 2008), Islamic fashion (Nef-Saluz 2007), billboard advertisements (Abdullah and Sairin 2003) and TV gossip news (Yulianto 2008). University students live in a hybrid space of local and international stimuli from the West, Asia and the Middle East. These spheres are not perceived as oppositional, but rather overlapping, coalescing, and, perhaps, becoming compatible. In respect of religion, for instance, college students do not reside in two different worlds, in a devout one and in a secular one, and neither do they switch between the two (Nef-Saluz 2007).

In the study of cinema in south-east Asia, Harvey recognises that a new generation of films possesses 'nomadic trajectories', namely polymorphous qualities that travel between 'imaginaries of the national and logics of the trans(national)' (2007, 273). Similarly, Khoo acknowledges the tensions that operate beneath indie movies, where local experiences are 'saturated into global popular culture, capitalist consumption, media and technological networks, and the flows of human creativity, labour, thought and emotion' $(2008,232)$. Hanan shows how films are concerned with reinventing and preserving traditions even as they embrace a culture of the future (2008).

The concept of grounded cosmopolitanism can provide scholars with the necessary basis to understand shifts in how contextual subjectivities (i.e. ethnic, religious, national) are interconnected with universalist phenomena (Kahn 2004). In grounded cosmopolitan theory, local and national belongings are regarded as important as allegiance to humanist and global influences, because everyone has specific but multiple subject positions. This conceptual approach does not refer to the old ideal of cosmopolitanism, of Immanuel Kant, for example, which suggests the irrelevance of ethnic and national boundaries in the worldwide community of human beings (Brown and Held 2010). 
Setijadi applies grounded cosmopolitan theory to the analysis of Indonesian independent cinema (2012). She examines the narrative plots, the film-makers' aspirations and the state of the film industry. She identifies three key motivations underpinning the film-makers' choice to reframe local issues as universal problems: (1) to express their grounded and cosmopolitan identities, (2) to critique and transcend rigid categorisations and instrumentalisation of differences and (3) to facilitate access into international film circuits. Expanding from Setijadi's analysis, this article shows how cosmopolitan subjectivities and their underlying motives are not exclusive traits of young indie film-makers, but can be stretched to youth in general. In addition, this paper illustrates that when grounded cosmopolitan forces are illustrated cinematically, abstract notions become tangible and films become pedagogical tools.

\section{Brief overview of Indonesia}

Indonesia has been one of the most cosmopolitan areas in the world, with a history of cultural receptiveness and religious synthesis of imported dogma and local spirituality. Indonesia has over 375 ethnic groups, 700 languages, six officially recognised religions (i.e. Islam, Protestantism, Catholicism, Hinduism, Buddhism, and Confucianism), the greatest number of Muslims in the world and the fourth highest population on the planet (i.e. over 237 million inhabitants) scattered across 6,000 inhabited islands. Tensions are evident in relation to a religious majority (Muslim) vs. a minority (non-Muslim). Eighty-seven per cent of Indonesians are Muslim, but more significant in this respect is the fact that the ethnic Javanese, who are almost entirely Muslim (and constitute only $40 \%$ of the population) wield most of the political power.

Regionality, ethnicity and religion are key identity-markers in Indonesia, because asal (origin) determines suku bangsa(ethnicity) and agama (religion) (Song 2008). This construction privileges Muslim Javanese due to their numerical and sociopolitical weight. It marginalises all other groups, especially Chinese-Indonesians who have been perceived as opposite topribumi (sons and daughters of the soil) or asli (indigenous) since the colonial era through geographical, cultural, economic and constructionist explanations (Heryanto 1998, 2004, 2008). This construction also conceals the heterogeneity within each categorisation, including Islam, which has many practices, beliefs and political viewpoints between the extremes of liberal and radical Muslims (Fealy and Sally 2008). In addition, it ethnicises religion so that each faith is attached to certain ethnic groups.

In Indonesia, the constitution formalises both monotheism and indigenous privileges (Heryanto 2008; Parker and Hoon 2013). The first rule of the national ideology Pancasila (Five Principles) imposes the belief in one God. By law, citizens must choose one of the six legally accepted religions and record it on their identity cards - a visible mark that carries serious consequences in everyday life. While the national motto Bhinneka Tunggal Ika evokes the ideal of 'Unity in Diversity', difference is accepted within the strict limits of what is still perceived as being 'Indonesian' (Bigalke 2007; Martano 2009). The term ethnicity, suku bangsa, literally means 'a constituent part of the nation', because ethnic (and ethnicised religious) groups are subordinate to the nation-state, Indonesia (Aspinall 2009). 
In this politicised context, the university has emerged, imbued with ethnicity, religion and nationalism. Indonesian higher education has made remarkable advancements in its relatively young life. The number of university students has increased from 200 in 1938 to over 6 million in 2012 (Cummings and Kasenda 1989; UNESCO 2012). Every year, more than 450,000 high school seniors take the national public university entrance examination to compete for 75,000 seats (Nizam 2006). Historically, college students have also been instrumental in the turning points of the country, including independence in 1945 and the return of democracy in 1998 (Altbach 1999). According to the law on Tri Dharma (Three Teachings), instruction, research and community service are the objective of higher education, because the advancement of knowledge should benefit the country as a whole (Buchori and Malik 2004).

The massification of higher education has brought tremendous challenges in providing adequate quality of teaching, material and facilities for its diverse student body (Buchori and Malik 2004; Tadjudin 2009). Indonesian education has generally adopted an accommodative or selective form of multiculturalism, meaning that the Javanese Muslim culture remains dominant but makes some provisions for the needs of minority groups (Sunarto, Russell, and Achmad Fedyani 2004). For instance, the contributions of minorities are not mentioned in textbooks, the capital city of Jakarta remains the centre of the educational system and divergent thinking is usually not encouraged (Adam 2003; Sunarto, Russell, and Achmad Fedyani2004). Interreligious dialogue is almost nonexistent, and all students are required to study their own religion, from kindergarten to college. Studying a different faith from their own is not allowed, so students' knowledge about other religions is limited.

Seventy-four per cent of all Indonesian college students are clustered on the island of Java, where the majority of universities and all premier institutions are located (Buchori and Malik 2004; Nizam 2006). In academia, essentialist and ethnocentric interpretations of culture remain prominent, whereas socialisation to cultural hybridity is rare (Heryanto 1998). In more recent years, universities have also turned into a breeding ground for underground extremist Islamic networks (Chandrakirana and Chuzaifah 2005). Insufficient funding, human resources and political will as well as social disparities are obstacles to create universities that can fulfil their potential as contact zones. Despite these limitations, public and co-educational universities with no religious affiliation are the most diverse spaces in the Indonesian social fabric. They are the focal points of the film $\operatorname{Cin}(T) a$ as well as of this paper.

\section{Reading $\operatorname{Cin}(T) a$ \\ State of the film industry}

Cin(T)a emerged from the cultural effervescence that followed the fall of Suharto's dictatorship. For 32 years, from 1966 to 1998, the regime had controlled cultural production through the socalled SARA restrictions, which had banned any texts about ethnicity (suku), religion (agama), race (ras) or class (antar-golongan) (Heryanto 2008; Ida 2008). Chinese-Indonesians had been targeted through assimilation policies that attempted to erase all things Chinese (e.g. schools, organisations, media, languages, celebrations). Students of all ages had been forced onto indoctrination courses (Song 2008). Since the end of the dictatorship, some of its legacies have 
persisted, but there has been a revival in cinema which has seen significant developments (Heryanto 2004, 2008).

First, films have become more varied in terms of cinematic styles and narrative themes (Agustina 2009; Rakhmani 2011; Setijadi 2012). They have attempted to play a social role of resistance by overcoming intergroup ignorance and hostility through the discussion of controversial subjects. For instance, Chinese-Indonesians have returned in both film characters and topics (Heryanto 2004, 2008; Setijadi 2012). Yet, the politics of indigenous/non-indigenous representations that are embedded in the social fabric of Indonesia endure. In addition, new threats to freedom of expression have come from both state and the growing control of Islamist puritanism (Clark 2008; Heryanto 2008; Setijadi 2012). Weak institutions, including the executive and judicial branches of government, play a key role in allowing a small number of radicals to paralyse the country. Therefore movies on sensitive topics, such as religious and ethnic differences, are still exceptions because film-makers are careful not to attract Islamist reactions or the state's persecution (Awal, Mau, and Febri 2011).

Second, the domestic production and consumption of pop culture have increased in tandem with the popularity of Asian media. South Korean television series have gained fame, alongside Hong Kong movies, Taiwanese pop music and Japanese comics (Heryanto 2004). The success of a 'peripheral nation's export' is contingent on cultural and geographical proximity (Ida2008, 109). These non-Western imported programmes provide alternatives to domestic productions, while offering a sense of familiarity in values and practices. Further influences come from the Middle East and its push for the purification of Islam (Nef-Saluz 2007).

Third, the reverberation of pop culture shows the hybridisation, plurality and ambiguity in identities as people and goods travel, physically or on TV, bringing with them cultural products from various sources and recreating them (Heryanto 2004). Younger independent filmmakers have begun to portray ethnic minorities not just as marginalised members of the local society, but as individuals whose lives and dreams are linked to universalist themes and contemporary trends experienced across the world (Setijadi 2012).

\section{Film-maker's aspirations}

Based on my conversation with director Sammaria Simanjuntak, the cosmopolitan approach to the film $\operatorname{Cin}(T) a$ is shaped by her personal hybrid world, disenchantment towards national politics and aspiration to participate in global cinema. Born in 1983 in Bandung (Java), Simanjuntak grew up in a middle-class family, watching American and European art films. A part of her is nested into $\operatorname{Cin}(T) a$, as a Christian, from the Batak ethnic minority, and a former straight-A student at the prestigious Bandung Institute of Technology (ITB). She lived in various parts of Indonesia and, after graduation, moved to Singapore to work as an architect, because she saw no opportunity for herself as minority member in Indonesia. Then she decided to return to her home country and started a career in films, despite her mother's pressure to get married instead.

Cin(T)a was filmed at her alma mater, ITB, due to easy access, low cost and familiar grounds. She recalled her college years as influential, because there she re-contemplated her personal desires, professional directions and understanding about social issues. On campus, she

Logli, C. Cultural studies in education: Filming fluid subjectivities in Indonesian universities. Pedagogy, Culture and Society, online first. http://www.tandfonline.com/eprint/VQvSIx9jn5tFFtQCbCbk/full 
grew intellectually through her studies in architecture and also explored her passion for cinema, by making her first short film with classmates of diverse backgrounds. Filming $\operatorname{Cin}(T) a$ was her contribution to challenging the status quo and shedding light on sensitive topics, such as interreligious and interethnic relationships. She frames these local predicaments from a humanist perspective, beyond the conventional ethno-nationalist approaches, by asking the audience universal questions about faith and love.

Simanjuntak is part of the increasing number of young women who have taken leading roles in the media (Heryanto 2008), where gender-related issues persist through homophobic images (Boellstorff 2005), narrow representations of masculinity (Clark 2008) and feminisation of celebrity news and sinetron (soap operas) (Yulianto 2008). As an emerging film-maker, she did not expect the wide acclaim that $\operatorname{Cin}(T) a$ received by both Indonesian and international audiences (Awal, Mau, and Febri2011; Ika 2012). Indonesian viewers praised the film for its accurate representation of reality and for its call to discuss diversity more openly (Cin(T)a blog, comments posted in 2009). Yet, Simanjuntak did foresee the criticisms among the conservative Muslim minority, who perceived the film as a misrepresentation of Islam, a distortion of the Quran and propaganda for religious pluralism (Undiabolos blog, comments posted in May 2010). These extremist voices are a minority in Indonesia, as shown by the fact that one of their affiliated online blog received sixteen 'likes' and sixty-five 'dislikes' (Kacahati blog, comments posted on 22 August 2009). Most Muslim commentators defined the critiques of Cin(T)a in this latter website as 'fanatic', 'embarrassing', 'shallow', and 'closed-minded', because 'sins and rewards are God's business'. All criticisms were religion-based - a confirmation of Simanjuntak's argument that religion is the most consequential identity maker.

\section{Deconstruction of the plot}

The subject of $\operatorname{Cin}(T) a$ is encrypted in the title: a story about love ('cinta') among Cina ('Cin'), God (' $\mathrm{T}$ ' as for Tuhan, God in Indonesian language) and Annisa ('A'). Cina is a Christian Chinese-Indonesian from Sumatra. He breaks the stereotypical representations of Chinese people as wealthy, because he is from a modest family and has to work to pay for his college degree. Annisa is a Muslim Javanese-Indonesian from the capital city of Jakarta. She is a famous actress but studies architecture, and feels lonely before meeting Cina. Tuhan is the most obscure protagonist, so the letter ' $\mathrm{T}$ ', in the title of the movie, is left blurred.

Set at ITB in the year 2000, the film features the weaknesses and strengths of Indonesian multicultural society. The movie starts by introducing Cina standing in his room in front of the Indonesian national emblem of the Garuda Pancasila and its motto Bhinneka Tunggal Ika (Unity in Diversity). A filming technique creates an optical illusion so Cina's face seems to be the sheer of the crest, as a reminder that minorities are also at the heart of the country. In addition, he shows his disillusion with demagogic politicians by displaying two mocking photographs of himself on each side of the insignia, where portraits of the Indonesian president and vice president would typically appear.

At the university, Cina and Annisa's private realms converge and bring evidence to intergroup contact theory. Without college connecting them, they would probably never have met. They both departed from their families and started a new life on their own in order to attend 
ITB, where they both major in architecture. Cina and Annisa start studying together and gradually enter into each other's worlds, discussing their religious beliefs, exploring their ethnic backgrounds and practising their distinct traditions together. Through these encounters, they overcome some of the prejudices and stereotypes that they had about each other.

Cina and Annisa's intercultural contact develops through two key dimensions of grounded cosmopolitanism. First, their philosophical conversations de-ethnicised grounded notions of ethnicity, religion and nation by highlighting humanistic values of justice, love and especially faith. Cina and Annisa raise subject matters perceived to be more 'universal' to show that local issues are interrelated with other matters that transcend contextual boundaries. At the same time, universal phenomena can only be experimented with through grounded experiences. For example, being a Christian Chinese-Indonesian has to do with feelings of isolation and anxiety, which are universalist emotions but can only appear through personal living.

Second, Cina and Annisa exhibit signs of adherence to both local and global influences. They employ a range of strategies to negotiate their individual identities in a hybrid environment where global influences meet local traditions, and their distinctive youth culture includes both religious law and global popular cultural trends. Through this hybridisation process, they integrate, reject or adapt global influences from the West, Middle East and the rest of Asia. On one hand, Cina and Annisa behave according to their religio-cultural traditions. For example, Annisa shows a connection with her Javanese and Muslim heritage, by cooking ketupat, having shadow puppets displayed in her house and receiving a flower bath before her wedding. On the other hand, Cina and Annisa think about studying abroad, insert English words in their speech, philosophise about Western thoughts and cut their hair as celebrities do in Asian cinema. As a modern Muslim, Annisa smokes, lives in her own apartment, interacts with men and is unveiled. This last choice is seemingly derived from her interpretation of the sacred texts concerning the female covering practice, but also for the meanings underlying the veil as a cultural form that is constructed, contested and intersecting (Nef-Saluz 2007).

In addition to their grounded cosmopolitanism, Cina and Annisa demonstrate critical agency and resistance to existing institutions, and in these ways illustrate instances of critical pedagogy. Cina criticises dominant groups for manipulating Islam in order to maintain their power. In moments of disillusionment about the country, he takes down the Indonesian national emblem of the Garuda Pancasila from the wall. As a senior student of architecture, Annisa's final project is a model for low-income public housing, which includes a recreational centre and unfinished floor plans inside the apartments. When questioned by her advisor, Annisa defends her vision by explaining that poor people also deserve a healthy lifestyle and the opportunity to design their own home. During the film, she often considers abandoning her thesis, because it had already failed three times and 'it will never be built, it does not matter'. She struggles against the gap between academia and society, theory and practice, critique and possibilities.

$\operatorname{Cin}(T) a$ also reveals how both formal and hidden curricula provide legitimacy to the dominant culture through a process of imposition of the habitus (i.e. meaning system) of one group onto that of another. Cina is introduced to the audience in his white uniform with a tie, which is a signifier of colonisation, Westernisation and gendered norms. He is running to his first day in college, moving within the imposed boundaries of time, schedule and calendar, which 
generally serve the needs of the global market economy. Despite his impeccable grades, he is unable to secure a scholarship because of his minority status. The university corridors and halls are portrayed as empty and claustrophobic spaces. During her thesis defence, Annisa stands against a white wall, under a spot light, in a site that evokes an interrogation chamber rather than a classroom. The teacher is invisible but her words of disapproval fill the scene. Rather than nurturing the student's abilities to ask critical questions and to propose innovative ideas, the instructor promotes a mindless acceptance of the status quo and dominant-elite view, which leads to conformity. Another interesting point in the film is that the protagonists show little knowledge of each other's faith, which is not surprising due to the absence of interfaith studies in Indonesia. Cina and Annisa's relationship ends on 24 December 2000, when Eid-al-Fitr coincided with Christmas Eve. After decorating the Christmas tree and breaking the Ramadam fast together, they are devastated by the news that the Islamic terrorist network Jemaah Islamiyah (JI) set over 30 bombs in churches in eleven cities across six provinces (International Crisis Group, 2002). In the reality of Indonesia, such violent incidences create an atmosphere of suspicion across religious communities. In the film, a man at a restaurant speculates that the bombing was caused by non-Muslims, to stain the reputation of Islam and to provoke raw reactions.

Following their parents' suggestions, Cina moves to Singapore and Annisa accepts an arranged marriage to a wealthy Chinese Muslim businessman. Cin(T)a confirms Heryanto's argument that marrying Javanese people or converting to Islam is used as a way of assimilation, but does not turn a Chinese-Indonesian into a pribumi (native) (1998). Cina and Annisa's separation reflects how the university is unable to fulfil its potential as a contact zone due to social constructs of otherness. Of all these forces, religion becomes the ultimate invisible divider between Cina and Annisa, just like the faded ' $T$ ' in between 'Cin' and ' $A$ ' in the film title.

On the one hand, the film-maker inserts in the film real interviews with interfaith couples to show that happy-ending relationships do exist. These voices, together with Cina and Annisa's profound connection, prove that love can transcend social stigmas. On the other hand, the couple in the film show that differences in faith are stronger than divides based on ethnicity, regionality, class and age. Their break-up is not aligned with the genre of 'teenage film' (film remaja), in which, according to Sen and Hill, young people's unruly behaviour is resolved through growing up, assimilating into the adult world and accepting social rules (2000). Rather, the film-maker's ultimate decision to move away from a happy-ending discourse is significant, because it reflects the current atmosphere of religious polarisation in Indonesia and globally.

\section{Empirical confirmations}

My research brings further evidence to the theoretical framework and film analysis that I have proposed in this paper (Logli2015; forthcoming). I focus this section on 633 survey returns and 31 interviews with students at Gadjah Mada University in 2012. As shown in Cin(T)a, public universities mirror the complexities of the surrounding multicultural society and provide students with a once-in-a-lifetime opportunity for connecting with peers from all corners of Indonesia. As never before, students are faced with national diversity and often suffer an initial 'cultural shock' in their words, especially if they graduated from mono-religious high schools. As the first semester goes by, students develop relationships with peers of all backgrounds through their 
coursework, campus organisations and housing as well as the overall college life. On a line from 'common' to 'rare', interethnic friendships are first, interfaith friendships are second, intercultural dating is third and interreligious dating is last. Religious difference is also the most sensitive topic and is discussed among close friends only. Yet, all these diverse relationships emerge more easily in college than in other contexts. Study participants unanimously point to diverse encounters as the most unique and transformative experience at the university. Their accounts of falling in love, building friendships and growing as a person expand beyond majority-minority dichotomies and connect with universalist experiences. For example, in the mist of the international unrest that followed the anti-Islamic film 'Innocence of Muslims', students wrote mass text messages that transcended grounded divides and grew from humanistic principles, such as 'we are one and in peace'.

Like Cina and Annisa, college students' hybrid identity arises in numerous forms, particularly in the context of the internationalisation of education. Students are proud of being part of a 'world class university' and appreciate its global atmosphere with international students, faculty, standards, degrees and programmes. They want 'to connect with other cultures and to have friends all over the planet'. Minority students appreciate the presence of non-Muslim foreign students because it encourages the university to be more inclusive, for instance, by keeping the cafeteria open during Ramadan and offering courses that are relevant for a wide audience. Their personal and academic lives are infused with virtual connections, through ebooks, blogs, online news, social media and Blackberry personal messages. However, they also believe that 'universities have to be national before becoming international', meaning that campuses have to represent the diversity of the country. Domestic and global phenomena are framed in terms of and not or, because they are both approached as important and complementary.

First, students' hybridity emerges through their reflections about demographic diversity on campus. A student says that 'the university is open to people from different countries, but not so much to minorities (i.e. non-Muslim and non-Javanese)'. Supporting all Indonesian communities is imperative for the well-being of the nation because 'protecting local cultures (smaller scope) directly leads to protecting the country (bigger scope)'. Students advise that the cultural night should not feature foreign students and their countries only, but also Indonesian communities and their provinces. They value faculty with a degree from overseas because it provides broader perspectives, yet highlight that 'it would be much better if professors also brought different backgrounds within Indonesia'. They recognise that college selection in Europe is found on merit alone since schools tend to have the same infrastructures, but university admission in Indonesia should be built on affirmative action so that all provinces are represented despite the disparities in the quality of primary and secondary schooling between Java and the rest of the archipelago. Students enjoy popular culture and global goods, and simultaneously criticise universities that only care about financial gains - 'when the willingness of the university is driven by the market, getting understanding across cultures and religious differences gets no place'.

Second, students' hybridity appears in their considerations about the university curricula. Students find English trendy and appealing, yet they also enjoy speaking Indonesian and their 
local languages. An interviewee recalls that he dropped out from a pesantren (boarding school) because pupils could speak English and Arabic only, and were punished physically if heard communicating in Indonesian or their native language. Students admire both national and international authors. They reflect on the problematic relationships between contextual and broader perspectives. On the one hand, for instance, some students claim that 'the West needs a deeper understanding of Eastern views of Islam and cannot force the world to accept one interpretation - for example of democracy and freedom - while neglecting all the other views, especially religious views'. On the other hand, some peers criticise Muslim lecturers who reframe Western theorists within Islam or promote their pious beliefs, because students adhere to different religions and teaching should be secular. For instance, students criticise lecturers who compared veiled women to beautifully wrapped candies and excused gender discrimination based on religious interpretations. Students also believe that Indonesia and the rest of the world can learn from one another. Indonesian universities should use 'local wisdom to resolve global issues and to inspire the world'. Academic discussions should bring different cultural and disciplinary insights together to resolve widespread predicaments. For instance, mono-religious classes should be replaced with 'multi-religion perspectives about current issues, like corruption and food security, so that faiths can have better social engagement'.

Third, students' hybridity becomes apparent through campus life. Students commit to organisations that are active locally and globally, such as on campaigns in support of Muslims in Myanmar and Palestine. A member of the campus newspaper explains that she is passionate about her work because 'when you are reporting you are a citizen of the world'. Students are concerned about international fundamentalist Islamic movements that infiltrate campus organisations and experience no resistance from the administration. Students condemn terrorism and find fundamentalists' hatred against the West unreasonable since 'extremists use cars, cell phones, TV, internet, weapons which are all Western products'. They also criticise the Wahhabi pressure from the Middle East, which 'insist that being Muslim is being like people in the Middle East - Indonesia is different in concepts so Indonesian Muslims are different from Middle Eastern Muslims like Indonesian Catholics are different from Italian Catholics'. They suggest universities have interfaith halls, rather than Muslim mosques only, 'like in Europe, where airports provide a silent room so all people can pray or mediate'. They are aware of their own cultural requirements, yet are also willing to make some accommodations. On the one hand, for instance, pleasing parents remain a key consideration for young people, including, for example, joining a prestigious programme at a university so 'it is not embarrassing for the family'. On the other hand, students are proud of a lifestyle that is wider than their parents' expectations, including travelling across Indonesia, studying abroad, dating peers from other countries, and dressing and behaving in a more worldly way.

These students' reflections demonstrate critical agency, as they recognise current hegemonic mechanisms and propose subaltern counter-public resolutions. The discourse of critique and possibility is often limited to discussions with peers, but sometimes expands to writing critical theses, confronting faculty, protesting rector's decisions and engaging in student activism. Efforts that support hybridity are increasing on campus. New approaches to community service and ad hoc courses on civic, moral and multicultural education attempt to foster broader 
civic engagement. Some professors support counter-hegemonic learning, such as self-reflections, critical pedagogies and contextual theologies. Both Javanese Muslim and minority faculty members create a space to problematise the meaning of being Indonesian. Many academic and executive members advocate for the recruiting of students across social divides.

Various forces misinterpret or restrict students' hybrid identity, including within the administration, faculty and students themselves. Universities that do not foster diversity through admission and retention limit students' exposure to a multiplicity of cultural references which shape hybrid identities. Some professors are concerned about the negative repercussions of both parochial belongings and global capitalism on students - including the prevalence of the English language, individualistic values and homogeneous cultures - rather than seeing them as integrated in a more complex blend. Strict Muslim students consider globalisation as a substitute, rather than a companion, of grounded allegiances and argue that 'many youths do not know their identity, do not show their religion, and do not consider national values like Bhinneka Tunggal Ika because they like popular culture'. As in $\operatorname{Cin}(T) a$, they also claim that terrorist attacks are 'False Flag Operations', in their words, a belief that further divides society with distrust.

\section{Implications for education}

In Hefner's words,

As the German democratic theorist, Jurgen Habermas, and, in Indonesia, Nurcholish

Madjid have both emphasised, a key feature of any democracy is not merely the formal institutions of elections and courts, but the creation of a vibrant public sphere in which citizens are free to debate, listen, and reflect without censure or intimidation. $(2002,1)$ State universities are critical parts of any democratic public sphere, as they provide remarkable opportunities for collective discussion, intellectual engagement and attempts to resolve today's most pressing problems. They also stand as ripe terrains for intercultural encounters. As Pratt advocates, the challenge for educators 'remains to figure out how to make that crossroad the best site for learning that it can be', in order to ensure a diverse and inclusive educational environment $(1991,6)$. Among other possible pedagogical strategies, films and artefacts provide a site where assumptions about dichotomies of 'us-versus-them' can be disrupted.

This article asked how universities serve as a contact zone for students of distinct backgrounds. To answer this question, I examined the Indonesian film $\operatorname{Cin}(T) a$, which explores the interfaith and multiethnic love between two college students. By featuring a controversial subject and presenting opposite perspectives, $\operatorname{Cin}(T) a$ generates a dialogue with viewers about (re)constructing new ways of life. The movie reflects as well as affects reality, and becomes a fruitful arena for learning when read critically, contextually as well as broadly. Cin(T)a is an example of pop culture that is not just an object of entertainment and commodity for profit, but also a pedagogical instrument (Holmes 2007; Maudlin, Sandlin, and Thaller 2012).

In my courses on education in a public university in the Pacific Rim, I have screened $\operatorname{Cin}(T) a$ to demonstrate how artefacts mirror, and sometimes critique, everyday practices around cultural representations, so that students can discuss assumed meanings and hidden complexity. The analysis of the state of the film industry, the film-maker's aspirations, deconstruction of plot and empirical confirmations expose students to new knowledge about a 
country, Indonesia, that they know little about despite its importance in the global landscape. It also illustrates cultural phenomena that are relevant for teachers' preparation in any multicultural society. As current or future educators, viewers ponder their manifold identities and perceptions about the Other, who may appear in their classrooms both among pupils and in the curricula. Participants examine how their personal values can have a role in either hindering or promoting social change, regardless of the subject that they teach. At least half of the classes I have worked with mentions faith (i.e. Christianity) as one of their top three identity markers and view it as a positive influence on their philosophy of teaching, rather than a possible exclusivist stand against pupils of different denominations. Students think about their biased reactions to the Islamic depictions in the film as well as in the mass media at large. They struggle with the recognition of religious diversity within all faiths and of destructive manipulation of creeds by invested parties, including their own. Students who advocate for a separation between religion and schooling are careful in expressing their perspectives, because they perceive differences in faiths as more sensitive than all other divides, such as ethnicity or class. In small groups, students revisit their philosophy of teaching and the purpose of education, with closer attention to matters of representations and public good. Together, they consider conceptual approaches and pedagogical strategies so that religions can be used as a support for inclusive teaching rather than a divisive force.

Through these intellectual exercises, students begin to understand their own fluid subjectivities as holding both grounded (i.e. ethnic, religious, national) and cosmopolitan (i.e. humanist and global) allegiances. They recognise the ethnicised and politicised nature of metanarratives and archetypes, and yet attempt to transcend them. They acknowledge cultures as contextually fluctuating conceptual variables, whose boundaries harden when instrumentalised. They move beyond conventional ethno-nationalist frameworks and open to the greater shared human experiences of empathy and justice. By experiencing authentic and respectful class discussions, participants realise that teaching about controversial topics is possible and essential in an intellectual environment that aims to contribute to the flourishing of the whole person. My experience with films as pedagogical tools has confirmed Rantala's argument that, through media education, students develop (1) connections between their everyday cultural worlds and school work, (2) practices for identity construction across multiple contexts and (3) navigational skills and intercultural competencies for bringing into conversation competing discourse communities, in order to challenge and reshape the status quo (2009). My use of artefacts as educational projects also echoes Dehli's claims that media education fosters autonomy, choice, initiative and creativity in students (2009). Students are more prone to engage in class, to take responsibility for their positionality, to respond constructively and to engage in dialogue collaboratively. Critical literacy is important and legitimate not just for media education but for all topics, because it relates to the ability to de-code socially constructed 'texts' and make conscious assessments.

Dialogue engendered by films and other art forms assists schooling in fulfilling its potential as a contact zone and third space - a learning arena where students in any community can draw on fluid subjectivities and multiple recourses to make sense of the world (Huhtala and Lehti-Eklund 2010; Kostogriz and Tsolidis 2008). Third spaces are spatial and discursive 
cultural crossroads for the construction of contingent and fluid identities in multicultural geopolitical situations. They are dynamic hybrid places of ambiguities, contradictions and continuous change. They are borderland zones of negotiation, where people can experiment with different positions and create something new. In this in-betweenness, the self can recognise 'usversus-them' binaries, negotiate tensions for identity-making, engage in genuine dialogues and create new trans-cultural meanings.

\section{References}

Abdullah, Irwan, and Sjafri Sairin. 2003. Viewing Yogyakarta through billboard media. Urban Culture Research 1: 103-116.

Adam, Asvi. 2003. The Chinese in the collective memory of the Indonesian nation. Kyoto Review of Southeast Asia 3, http://kyotoreview.cseas.kyotou.ac.jp/issue/issue2/article_244_p.html.

Agustina, Rizka. 2009. Cin(T)a: The beauty of pluralism. The Jakarta Post, August 30.

Allport, Gordon. 1954. The nature of prejudice. Cambridge, MA: Addison-Wesley.

Altbach, Philip. 1999. Student power. Change 31, no. 5: 52, 57.

Anderson, Benedict. 2006. Imagined communities: Reflections on the origin and spread of nationalism. London, UK: Verso.

Antonio, Anthony. 2004. When does race matter in college friendships? Exploring men's diverse and homogeneous friendship groups. The Review of Higher Education 27, no. 4: 553-575.

Aspinall, Edward. 2009. Islam and nation: Separatist rebellion in Aceh, Indonesia. Stanford, CA: Stanford University Press.

Awal, Dini, Muliadi Mau, and Alem Febri. 2011. Konstruksi realitas perbedaan SARA dalam film $\operatorname{cin}(T)$ a [Construction of reality according to SARA in the film $\operatorname{cin}(T) a$ ], Communication, Hasanuddin University, Makassar, Indonesia.

Bigalke, Terence. 2007. Ten keys to understanding Indonesia. Education about Asia 12, no. 1: 12-16.

Boellstorff, Tom. 2005. Between religion and desire: Being Muslim and gay in Indonesia. American Anthropologist 107, no. 4: 575-585.

Bokhorst-Heng, Wendy. 2007. Multiculturalism's narratives in Singapore and Canada: Exploring a model for comparative multiculturalism and multicultural education. Curriculum Studies 39, no. 6: 629-658.

Bourdieu, Pierre. 1979. Les trois états du capital culturel [The three stages of cultural capital]. Actes de la recherche en sciences sociales 30, no. 1: 3-6.

Brown, Garrett, and David Held. 2010. The cosmopolitanism reader. Cambridge, UK: Polity Press.

Buchori, Mochtar, and Abdul Malik. 2004. The evolution of higher education in Indonesia. In Asian universities: Historical perspectives and contemporary challenges, ed. Philip Altbach and Toru Umakoshi, 249-277. Baltimore, MD: Johns Hopkins University Press.

Chandrakirana, Kamala, and Yuniyanti Chuzaifah. 2005. The battle over a 'new' Indonesia: Religious extremism, democratization and women's agency in a plural society. In Muslim women and the challenge of Islamic extremism, ed. Norani Othman, 49-77. Selangor, Malaysia: Sisters in Islam. 
Chavous, Tabbye. 2005. An intergroup contact-theory framework for evaluating racial climate on predominantly white college campuses. American Journal of Community Psychology 36, no. 3/4: 239-257.

Cin(T)a. Directed by Sammaria Simanjuntak. Bandung, Indonesia: Sembilan Matahari Film, 2009.

Cin(T)a blog. http://godisadirector.wordpress.com.

Clark, Marshall. 2008. Indonesian cinema: Exploring cultures of masculinity, censorship and violence. In Popular culture in Indonesia: Fluid identities in post-authoritarian politics, ed. Ariel Heryanto, 37-53. New York City, NY: Routledge.

Crossley, Nick, and John Roberts. 2004. After Habermas: New perspectives on the public sphere. Oxford, UK: Blackwell.

Cummings, William, and Salman Kasenda. 1989. The origin of modern Indonesian higher education. In From dependence to autonomy: The development of Asian universities, ed. Philip Cummings, William, and Salman Kasenda. 1989. "The Origin of Modern Indonesian Higher Education." In From Dependence to Autonomy: The Development of Asian Universities, edited by Philip Altbach and Viswanathan Selvaratnam, 143-166. Boston, MA: Kluwer Academic.

Altbach, and Viswanathan Selvaratnam, 143-166. Boston, MA: Kluwer Academic.

Dehli, Kari. 2009. Media literacy and neo-liberal government: Pedagogies of freedom and constraint. Pedagogy, Culture and Society 17, no. 1: 57-73.

Duara, Prasenjit. 1996. De-constructing the Chinese nation. In Chinese nationalism, ed. Jonathan Unger and Geremie Barmé, 31-55. Armonk, NY: M.E. Sharpe.

During, Simon. 2007. The cultural studies reader. New York City, NY: Routledge.

Engberg, Mark. 2004. Improving intergroup relations in higher education: A critical examination of the influence of educational interventions on racial bias. Review of Educational Research 74, no. 4: 473-524.

Fealy, Greg, and Sally White. 2008. Expressing Islam: Religious life and politics in Indonesia. Singapore: Institute of Southeast Asian Studies.

Foucault, Michel. 1995. Discipline and punish: The birth of the prison. New York City, NY: Vintage Books.

Fraser, Nancy. 2007. Rethinking the public sphere: A contribution to the critique of actually existing democracy. In The cultural studies reader, ed. Simon During, 488-506. New York City, NY: Routledge.

Geertz, Clifford. 1973. The interpretation of cultures: Selected essays. New York City, NY: Basic Books.

Giroux, Henry. 1988. Teachers as intellectuals: Toward a critical pedagogy of learning. Granby, MA: Bergin \& Garvey.

Halualani, Rona, Anu Chitgopekarb, Jennifer Huynh, Thi Ahn Morrison, and Patrick ShaouWhea Dodge. 2004. Who's interacting? And what are they talking about? Intercultural contact and interaction among multicultural university students. International Journal of Intercultural Relations 28: 353-372.

Hanan, David. 2008. Changing social formations in Indonesian and Thai teen movies. In Popular culture in Indonesia: Fluid identities in post-authoritarian politics, ed. Ariel Heryanto, 54-69. New York City, NY: Routledge.

Harvey, Sophia. 2007. Nomadic trajectories: Mapping short film production in Singapore. InterAsia Cultural Studies 8, no. 2: 262-276. 
Hefner, Robert. 2002. Civil Islam and democracy reconsidered. Kultur: Indonesian journal of Muslim cultures 2: 1 .

Heryanto, Ariel. 1998. Chinese Indonesians in public culture: Ethnic identities and erasure. In Southeast Asian identities: Culture and the politics of representation in Indonesia, Malaysia, Singapore, and Thailand, ed. Joel Kahn, 95-114. New York City, NY: St. Martin's Press.

- 2008. Popular culture in Indonesia: Fluid identities in post-authoritarian politics. New York City, NY: Routledge.

- 2004. Ethnic diasporas as cosmopolitans? Indonesian Chineseness, citizenship, and pop cultures. In Ethnicities, Diasporas and 'Grounded' Cosmopolitanisms in Asia, workshop proceeding, 26-41. Singapore: Asia Research Institute at the National University of Singapore.

Hobsbawm, Erik, and Terence Ranger. 1992. The Invention of tradition. Cambridge, UK: Cambridge University Press.

Holmes, Rachel. 2007. East is East: Using film to disrupt university classroom narratives around childhood and identity. Pedagogy, Culture and Society 15, no. 3: 367-384.

Huhtala, Anne, and Hanna Lehti-Eklund. 2010. Writing a new self in the third place: Language students and identity formation. Pedagogy, Culture and Society 18, no. 3: 273-288.

Hytten, Kathy. 1999. The promise of cultural studies of education. Educational Theory 49, no. 4: 527-543.

Ida, Rachmah. 2008. Consuming Taiwanese boys culture: Watching Meteor Garden with urban Kampung women in Indonesia In Popular culture in Indonesia: Fluid identities in postauthoritarian politics, ed. Ariel Heryanto, 93-110. New York City, NY: Routledge.

Ika, Krismantari. 2012. Sammaria Simanjuntak: For the love of film. The Jakarta Post, March 26.

Jiang, Yi-huah. 2006. Is Taiwan a nation? On the current debate over Taiwanese national identity and national recognition. In The dignity of nations: Equality, competition, and honor in East Asian nationalism, ed. Sechin Chien and John Fitzgerald. Hong Kong: Hong Kong University Press.

Kacahati blog. http://kacahati.wordpress.com/2009/08/22/jangan-nonton-film-cinta1 .

Kahn, Joel. 2004. Introduction: Identities, nations and cosmopolitan practice. In Ethnicities, Diasporas and 'Grounded' Cosmopolitanisms in Asia, workshop proceeding, 2-9. Singapore: Asia Research Institute at the National University of Singapore.

Khoo, Gaik. 2008. Urban geography as pretext: Sociocultural landscapes of Kuala Lumpur in independent Malaysian films. Singapore Journal of Tropical Geography 29, no. 1: 34-54.

Kostogriz, Alex, and Georgina Tsolidis. 2008. Transcultural literacy: Between the global and the local. Pedagogy, Culture and Society 16, no. 2: 125-136.

Martano, Valeria. 2009. Unità nella diversità: Il modello indonesiano per una società del convivere (Unity in diversity: The Indonesian model for a coexisting society). Milano, Italy: Guerini e Associati.

Maudlin, Julie, Jennifer Sandlin, and Jonel Thaller. 2012. Baby culture and the curriculum of consumption: A critical reading of the film Babies. Pedagogy, Culture and Society 20, no. 2: 211-229.

Nagda, Biren, and Patricia Gurin. 2007. Intergroup dialogue: A critical-dialogic approach to learning about difference, inequality, and social justice. New Directions for Teaching and Learning 111: 35-45.

Logli, C. Cultural studies in education: Filming fluid subjectivities in Indonesian universities. Pedagogy, Culture and Society, online first. http://www.tandfonline.com/eprint/VQvSIx9jn5tFFtQCbCbk/full 
Nef-Saluz, Claudia. 2007. Islamic Pop Culture in Indonesia: An anthropological field study on veiling practices among students of the Gadjah Mada University of Yogyakarta. Institut für Sozialanthropologie der Universität Bern 41.

Nilan, Pam, and Carles Feixa. 2006. Global youth?: Hybrid identities, plural worlds. London, UK: Routledge.

Nizam. 2006. Indonesia. In Higher education in South-East Asia, ed. UNESCO, 35-68. Bangkok, Thailand.

Parker, Lyn, and Chang Yau Hoon. 2013. Secularity, religion and the possibilities for religious citizenship. Asian Journal of Social Sciences 41, no. 2: 150-174.

Pratt, Mary. 1991. Arts of the contact zone. Profession 91: 33-40.

Rakhmani, Inaya. 2011. Questioning religious divides: A recent film supporting religious pluralism stirs public debate. Inside Indonesia 105.

Rantala, Leena. 2009. In search of third spaces in media education: An ethnographic study from fifth graders' media workshop. Pedagogy, Culture and Society 17, no. 3: 385-399.

Richter, Max. 2008. Other worlds in Yogyakarta: From jatilan to electronic music. In Popular culture in Indonesia: Fluid identities in post-authoritarian politics, ed. Ariel Heryanto, 164-181. New York City, NY: Routledge.

Robinson, Jerry, and James Preston. 1976. Equal status contact and modification of racial prejudice: A reexamination of the contact hypothesis. Social Forces 54, no. 4: 911-924.

Sen, Krishna, and David Hill. 2000. Media, culture and politics in Indonesia. New York City, NY: Oxford University Press.

Setijadi, Charlotte. 2012. Chineseness, belonging and cosmopolitan subjectivities in post-Suharto independent films. Chinese Indonesians Reassessed: History, Religion and Belonging 52, no. 65: 65-82.

Shin, Gi-Wook. 2006. Ethnic nationalism in Korea: Genealogy, politics, and legacy. Stanford, CA: Stanford University Press.

Smith, Anthony. 2003. Chosen peoples. Oxford, UK: Oxford University Press.

Song, Seung-Won. 2008. Back to basics in Indonesia? Reassessing the Pancasila and Pancasila state and society, 1945-2007. Ph.D. diss., Ohio University.

Sorensen, Nicholas, Biren Nagda, Patricia Gurin, and Kelly Maxwell. 2009. Taking a hands on approach to diversity in higher education: A critical-dialogic model for effective intergroup interaction. Analyses of Social Issues and Public Policy 9, no. 1: 3-35.

Sunarto, Kamanto, Russell Heng, and Achmad Fedyani Saifuddin. 2004. Multicultural education in Indonesia and Southeast Asia: Stepping into the unfamiliar. Depok, Indonesia: Jurnal Antropologi Indonesia.

Tadjudin, M. K. 2009. Quality assurance in Indonesian higher education. In Higher education in Asia/Pacific: Quality and the public good, ed. Terance Bigalke and Deane Neubauer, 147-164. New York City, NY: Palgrave Macmillan.

Undiabolos blog. http://bauntung-batuah.blogspot.com/2010/05/bahaya-film-cinta.html.

UNESCO. 2012. "Data center." UNESCO. http://stats.uis.unesco.org.

Wright, Stephen, Arthur Aron, Tracy McLaughlin-Volpe, and Stacy Ropp. 1997. The extended contact effect: Knowledge of cross-group friendships and prejudice. Journal of Personality and Social Psychology 73, no. 1: 73-90.

Yulianto, Vissia. 2008. Consuming gossip: A re-domestication of Indonesian women . In Popular culture in Indonesia: Fluid identities in post-authoritarian politics, ed. Ariel Heryanto, 130-142. New York City, NY: Routledge. 
Logli, C. Cultural studies in education: Filming fluid subjectivities in Indonesian universities. Pedagogy, Culture and Society, online first. http://www.tandfonline.com/eprint/VQvSIx9jn5tFFtQCbCbk/full 